\title{
PENGEMBANGAN MODUL FISIKA PADA MATERI FLUIDA MATA KULIAH FISIKA DASAR I UNIVERSITAS JAMBI
}

\author{
Melinda ${ }^{1}$, Menza Hendri ${ }^{2}$, Rahma Dani ${ }^{3}$ \\ ${ }^{1}$ Mahasiswa S1 Pendidikan Fisika PMIPA FKIP Universitas Jambi, Jambi, Indonesia \\ ${ }^{2,3}$ Dosen Pendidikan Fisika PMIPA FKIP Universitas Jambi, Jambi, Indonesia \\ Email: melindatamrin@ymail.com
}

\section{Info Artikel}

Diterima:

13 Februari 2018

Disetujui:

20 Maret 2019

Dipublikasikan:

15 Desember 2019

\begin{abstract}
Abstrak:
Tujuan penelitian ini adalah menghasilkan modul pembelajaran fisika pada materi fluida dan mengetahui persepsi mahasiswa terhadap modul tersebut. Penelitian ini termasuk penelitian dan pengembangan (Research and Development). Model pengembangan yang digunakan adalah ADDIE (Analyze, Design, Development, Implementation, and Evaluation). Modul pembelajaran fisika pada materi fluida mata kuliah fisika dasar 1 telah dinyatakan layak oleh validator. Hasil ujicoba modul diperoleh 85 (sangat baik) untuk aspek desain pembelajaran, aspek materi yaitu 85,07 (sangat baik), aspek keterbacaan modul yaitu 85,22 (sangat baik), aspek visualisasi modul yaitu 84,11 (sangat baik). Modul fisika dasar 1 materi fluida hasil pengembangan layak digunakan sebagai salah satu bahan ajar pembelajaran di kelas.
\end{abstract}

Kata kunci: Modul, Fluida, Fisika Dasar 1

\begin{abstract}
:
The purpose of this research is to produce a physics learning module on fluid material and to know the student's perception of the module. This research includes research and development. The development Model used is ADDIE (Analyze, Design, Development, Implementation, and Evaluation). The Physics learning module on the fluid material of basic Physics 1 courses has been declared worthy by the validator. Test Result module obtained 85 (very good) for the design aspects of learning, the material aspect is 85.07 (very good), the aspect of readability module is 85.22 (very good), the visualization aspect of the module is 84.11 (very good). The basic Physics Module 1 development fluid material is worth using as one of the learning teaching materials in the classroom.
\end{abstract}

Keywords: Modul, Fluid, Basic Physics I

\section{Copyright (C 2019 Edufisika: Jurnal Pendidikan Fisika}

\section{Pendahuluan}

Pada pendidikan tinggi atau universitas, capaian pembelajaran untuk program studi pendidikan fisika yaitu setiap lulusan S1 pendidikan fisika harus memiliki sikap dan tata nilai yang baik, penguasaan, pengetahuan, kemampuan bidang kerja, dan kemampuan manajerial. Oleh karena itu, mahasiswa harus mengambil mata kuliah wajib di program studi pendidikan fisika. Salah satu mata kuliah wajib pada program studi pendidikan fisika adalah fisika dasar 1. Capaian pembelajaran yang diharapkan dari mata kuliah fisika dasar 1 
adalah agar mahasiswa mampu memecahkan berbagai masalah yang berhubungan materi fisika dasar 1, menerapkan berbagai prinsip dasar mekanika, serta listrik dan magnet, untuk memecahkan masalah yang menyangkut sistem fisika dasar sederhana. Dari uraian tersebut, terlihat bahwa mata kuliah fisika dasar 1 mensyaratkan mahasiswa menguasai pengetahuan. Tetapi pada kenyataannya penguasaan konsep mahasiswa terhadap materi pada mata kuliah fisika dasar 1 masih rendah. Hal ini diperkuat dengan rendahnya hasil belajar mata kuliah fisika dasar 1 .

Berdasarkan observasi melalui angket dan wawancara dengan melibatkan beberapa mahasiswa pendidikan fisika universitas jambi, diketahui bahwa $73 \%$ dari responden mengatakan bahwa materi fluida adalah salah satu materi pada mata kuliah fisika dasar 1 yang sulit dipahami adalah. Salah satu penyebab sulitnya mahasiswa dalam memahami materi tersebut adalah buku penunjang yang digunakan berupa buku paket dan modul yang tidak mudah untuk dipahami serta tampilannya juga kurang menarik.

Keberhasilan dalam pembelajaran fisika khususnya pada mata kuliah fisika dasar 1 didukung dengan perangkat pembelajaran yang memadai. Salah satu perangkat pembelajaran yang dapat menunjang penguasaan konsep fisika dasar 1 adalah bahan ajar. Bahan ajar merupakan seperangkat materi yang disusun secara sistematis baik secara tertulis maupun tidak sehingga tercipta lingkungan/suasana yang memungkinkan mahasiswa untuk belajar.

Tidak semua jenis bahan ajar yang memiliki kelengkapan dalam penyusunannya. Bahan ajar yang lengkap yang merupakan satu kesatuan program yang dapat mengukur tujuan pembelajaran adalah modul. Modul dapat dipandang sebagai paket program yang disusun dalam bentuk susunan yang disusun dalam bentuk satuan tertentu guna keperluan belajar.

Berdasarkan uraian di atas, dapat disimpulkan bahwa pentingnya sebuah modul cetak ini untuk membantu mengatasi kesulitan mahasiswa dalam mempelajari materi fluida. Dari uraiaan diatas, rumusan penelitian ini adalah mengetahui hasil pengembangan modul pembelajaran fisika pada materi fluida mata kuliah Fisika Dasar 1 dan mengetahui persepsi mahasiswa terhadap modul pembelajaran fisika pada materi fluida mata kuliah Fisika Dasar 1.
Penelitian ini bertujuan untuk mengetahui hasil pengembangan modul pembelajaran fisika pada materi fluida mata kuliah Fisika Dasar 1 dan mengetahui persepsi mahasiswa terhadap modul pembelajaran fisika pada materi fluida mata kuliah Fisika Dasar 1. Manfaat dari penelitian ini adalah menghasilkan modul pembelajaran fisika pada materi fluida mata kuliah Fisika Dasar 1.

\section{Metode Penelitian}

Jenis Pengembangan

Jenis penelitian ini merupakan penelitian Research and Development (Penelitian dan Pengembangan). Menurut Sugiyono (2013) metode penelitan Research and Development adalah metode penelitian yang digunakan untuk menghasilkan produk tertentu dan menguji keefektifan produk tersebut. Model desain pengembangan yang digunakan adalah model pengembangan AADIE. Model ini sesuai dengan namanya, terdiri dari 5 fase atau tahapan utama, yaitu:
(A)nalysis,
(D)esign,
(D)evelopment,

\section{(I)mplementation dan (E)valuation.}

Prosedur Pengembangan

1. Tahap Analysis (Analisis)

Tahap Analisis ini meliputi:

(1). Analisis kebutuhan dan karakteristik mahasiswa, Adapun karakteristik yang diidentifikasi, yaitu : pada semester berapa produk ini akan digunakan? Modul ini ditujukan untuk mahasiswa Pendidikan Fisika Universitas Jambi yang telah mengontrak mata kuliah fisika dasar 1 sebanyak 30 orang. Pengembangan, dilakukannya pengembangan modul pada materi Fluida dikarenakan materi tersebut terdapat banyak rumus dan membutuhkan waktu yang cukup lama untuk memahami materi tersebut.

(2). Analisis kurikulum, Pada tahap ini dilakukan analisis kurikulum yang berguna untuk melihat silabus kurikulum yang digunakan di universitas, menetapkan kompetensi inti dan kompetensi dasar materi, serta indikator yang ingin dicapai sesuai dengan materi.

(3). Studi Literatur, Studi literatur dilakukan dengan mengumpulkan informasi yang dapat digunakan sebagai bahan untuk mendesain dan mengembangkan produk melalui buku sumber ataupun jurnal 
pendidikan. Langkah yang dilakukan peneliti dalam studi literatur ini adalah melengkapi kajian pustaka yang berkaitan dengan penelitian dan sumber-sumber yang dapat mendukung pembuatan produk sehingga penelitian dan produk yang dihasilkan bersifat ilmiah.

\section{Tahap Design (Perancangan)}

Tahap desain pengembangan modul ini meliputi beberapa tahap, yaitu:

(1). Jadwal pengembangan meliputi jadwal pembuatan produk, dimulai dari penganalisaan produk, pengumpulan bahan dan pembuatan produk yang menghabiskan waktu sekitar 2 bulan.

(2). Tim pengembangan modul ini memerlukan tim kerja yang terdiri dari 4 tim dengan masing-masing tugas dan peran masing-masing yang terdiri dari, penulis sebagai pengembang produk, tim ahli untuk menilai produk yang dihasilkan yang terdiri dari tim ahli media dan tim ahli materi dan mahasiswa sebagai penilai produk pada ujicoba kelompok kecil.

(3). Struktur modul menurut Daryanto, dkk (2014) dapat dijelaskan sebagai berikut :

a. Halaman sampul yang berisi antara lain: label kode modul, label milik sekolah/negara, bidang/program studi keahlian dan kompetensi keahlian, judul modul, gambar ilustrasi (mewakili kegiatan yang dilaksanakan pada pembahasan modul), tulisan lembaga seperti Departemen Pendidikan Nasional, Dirjen Manajemen Pendidikan Dasar dan Menengah, Direktorat Pembinaan dan tahun.

b. Kata pengantar

c. Daftar isi

d. Peta kedudukan modul

e. Glosarium

f. Pendahuluan yang berisi antara lain: standar kompetensi, deskripsi singkat modul, waktu, prasyarat, petunjuk penggunaan modul, tujuan akhir, dan cek penguasaan standar kompetensi.

g. Pembelajaran yang berisi antara lain: judul pembelajaran, kompetensi dasar, tujuan, uraian materi, rangkuman, tugas, tes, dan lembar kerja praktik.

h. Evalusi

i. Kunci jawaban j. Daftar pustaka

(4). Tahap pembuatan modul

Adapun tahap-tahap dari pembuatan modul ini adalah

a. Proses pengumpulan materi/bahan

Pengumpulan materi atau bahan ini berupa gambar dan teks yang diperoleh dengan mencari bahan materi dari internet atau buku yang ada kaitannya dengan materi fluida. Setelah pengumpulan materi selesai maka dibuatlah modul tersebut dengan menggunakan program Microsof Word 2007.

b. Desain pembuatan modul

Setelah dilakukan pengumpulan gambar dan teks yang mendukung materi yang akan dibuat Modul, langkah selanjutnya adalah menuangkan materi tersebut ke dalam program Microsoft Word 2007. Adapun desain dari modul ini dapat dilihat dari tabel berikut:

Tabel 1. Desan Modul Fisika

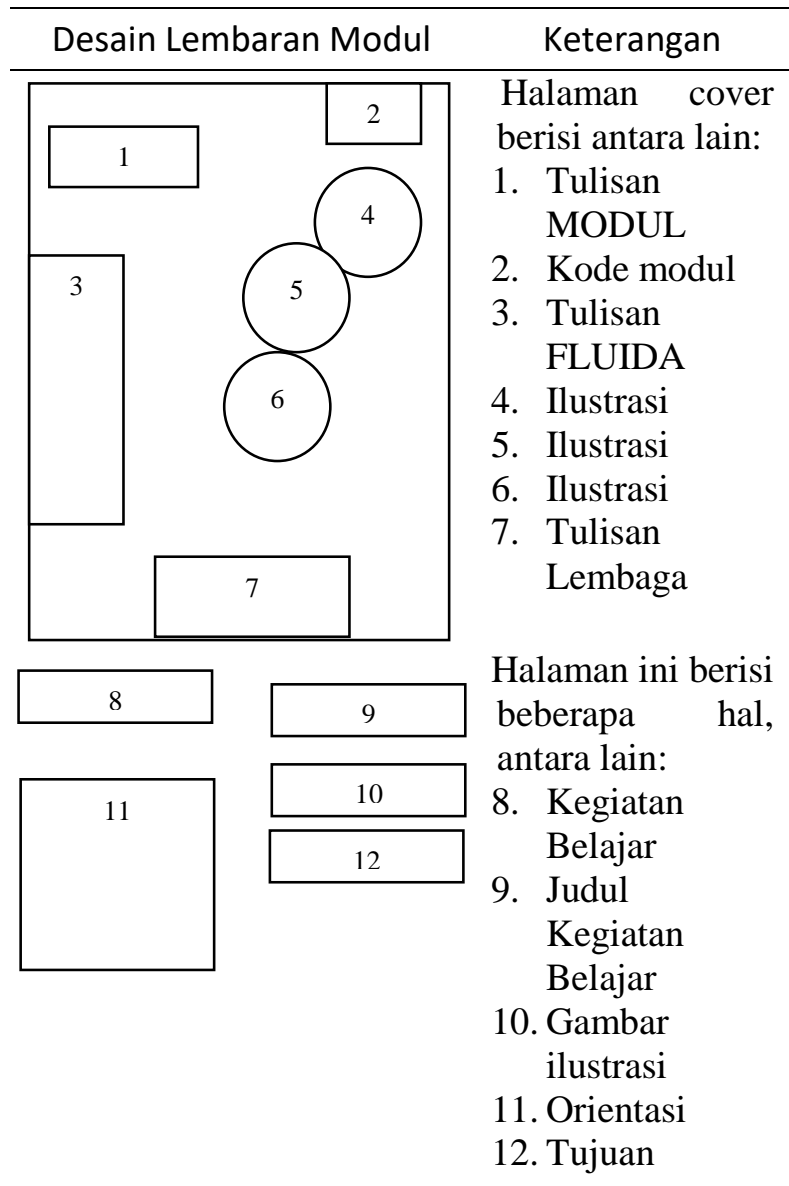


13. Halaman ini berisi uraian materi yang penting dipelajari.
13

14

15

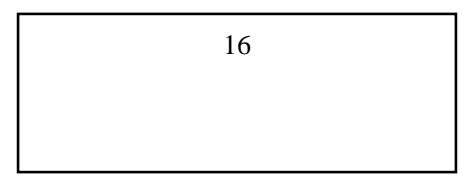

Uraian materi ini bertujuan untuk pemahaman terhadap konsep/penget ahuan/prinsipprinsip.

14. Halaman ini berisi tugas yang disertai dengan cara penyelesaiann ya

15. Tes formatif, pada bagian ini

mahasiswa dituntut untuk mengerjakan soal yang telah diberi

kunci jawaban sebagai bahan pengecekan bagi mahasiswa untuk mengetahui sejauh mana penguasaan hasil belajar yang telah dicapai

16. Pada bagian ini, berisi jawaban dari pertanyaan yang terdapat pada tes formatif c. Proses pengeprinan dan penyusunan

Setelah mendesain modul tersebut bisa diprint menggunakan kertas hvs dan selanjutnya disusun sesuai dengan halaman yang tertera pada modul.

3. Tahap Pengembangan (Development)

Berdasarkan prosedur pengembangan maka pada tahap pelaksanaan pengembangan perlu dilakukan ujicoba yaitu untuk mendapatkan pendapatan atau tanggapan mengenai kelayakan bahan ajar yang dikembangkan. Sebelum produk yang dikembangkan diujicobakan, produk ini terlebih dahulu divalidasi oleh tim ahli, yaitu ahli media dan ahli materi. Setelah dapat validasi dari tim ahli dilakukanlah revisi produk. Revisi produk dikatakan selesai apabila saran-saran validasi dari tim ahli sudah dianggap baik dan setelah itu baru tahap ujicoba kelompok kecil dilakukan. Revisi produk ini dilakukan, apabila dalam pemakaian kondisi nyata dilakukan untuk mendapatkan tanggapan mengenai produk yang dihasilkan melalui angket.

\section{Tahap Implementasi (Implementation)}

Pada tahap ini produk akhir merupakan produk hasil revisi yang telah divalidasi oleh tim ahli media dan tim ahli materi. Dimana produk yang dikembangkan sudah cukup baik untuk dapat diujicobakan kepada mahasiswa.

\section{Tahap Evaluasi (Evaluation)}

Pada tahap ini dapat dilakukan antar satu tahap dengan tahap lainnya. Disamping itu tahap evaluasi yang utama dilakukan melalui proses validasi produk oleh ahli media dan ahli materi, merevisi produk berdasarkan penilaian dan saran dari ahli media dan ahli materi serta melakukan ujicoba produk yang dikembangkan.

\section{Ujicoba Produk}

1. Desain Ujicoba Produk

(1). Uji validasi produk oleh ahli yaitu ahli materi dan ahli media

(2). Uji coba produk pada kelompok terbatas, dimana kelompok terbatas ini terdiri dari 10 mahasiswa pendidikan fisika Universitas Jambi yang telah mengontrak mata kuliah fisika dasar 1 yang merupakan mahasiswa pendidikan fisika PGMIPA-U 2016. 
2. Subjek Ujicoba Produk

Ujicoba dilakukan sebagai bahan pertimbangan dan perbandingan untuk menilai media yang dibuat. Subjek uji kelompok terbatas meliputi mahasiswa pendidikan fisika Universitas Jambi yang telah mengontrak mata kuliah fisika dasar 1.

\section{Jenis Data}

Dalam penilitian pengembangan ini, jenis data yang diambil yaitu data kualitatif dan kuantitatif. Data kualitatif berupa saran dan pernyataan kesesuaian modul berdasarkan analisis persentase tanggapan dari ahli media maupun dari ahli materi. Data kuantitatif yang diperoleh berupa isian angket persepsi mahasiswa terhadap penggunaan modul.

\section{Instrumen Pengumpulan data}

Adapun instrumen penelitian yang digunakan adalah kuesioner (angket). Kuesioner adalah teknik pengumpulan data yang dilakukan dengan cara membagikan seperangkat pertanyaan maupun pernyataan tertulis kepada responden untuk dijawab (Sugiyono, 2013),. Pada penelitian ini, angket yang digunakan dibedakan menjadi dua berdasarkan pengisi/responden, yaitu:

1. Angket untuk ahli materi dan ahli media

2. Angket untuk mahasiswa

Teknik Analisis Data

1. Angket Tim Ahli

Pada angket yang digunakan, digunakan pilihan jawaban bagi tim ahli berupa: ya/tidak Modul akan dinyatakan layak untuk dilanjutkan pada tahap selanjutnya apabila tim ahli memberikan jawaban "ya" pada pernyataan/pertanyaan yang disediakan di dalam angket. Selain memberikan penilaian dengan memilih jawaban yang telah disediakan, tim ahli juga akan memberikan saran terhadap modul di bagian kolom komentar yang telah disediakan di dalam angket.

\section{Angket Persepsi Mahasiswa siswa}

Dalam penelitian ini untuk mengetahui respon mahasiswa terhadap modul pembelajaran Fisika Pada Materi Fluida Mata Kuliah Fisika Dasar I adalah angket. Untuk mendapatkan data persepsi mahasiswa terhadap modul, maka dilakukan penyebaran angket kepada para mahasiswa yang dijadikan subjek uji coba. Data yang diperoleh dari penyebaran angket persepsi mahasiswa berupa data kuantitatif. Data kuantitatif yang diperoleh inilah yang nantinya akan dianalisis. Namun sebelum angket disebarkan kepada para responden, angket perlu diuji dengan menganalisis validitas dan reliabilitasnya. Adapun angket persepsi mahasiswa yang digunakan merupakan instrumen non tes, sehingga cukup melakukan validitas logis berupa validitas konstruk. Angket ini disusun berdasarkan kisi-kisi serta aspek-aspek yang akan diukur, selanjutnya dilakukan konsultasi angket terhadap ahli atau pada penelitian ini dilakukan pada dosen pembimbing.

Setelah angket dinyatakan valid, maka tahap selanjutnya adalah melakukan uji reliabilitas. Uji reliabilitas dilakukan dengan cara perhitungan koefisien korelasi dari persamaan Alpha. Dari penelitian sebelumnya yang dilakukan oleh Dina Marhami Isti (2014) diperoleh koefisien korelasi sebesar $\mathrm{r}_{11}=$ 0,814502571 . Hasil tersebut menunjukkan bahwa angket yang digunakan memiliki reliabilitas yang sangat tinggi sehingga bisa dipercaya dan bisa digunakan untuk mengambil data yang diinginkan, yaitu data persepsi mahasiswa terhadap modul cetak fluida yang dikembangkan.

Analisis data menggunakan skala Likert. Instrumen angket ujicoba tersebut memiliki jawaban berupa data kuantitatif dengan pilihan jawaban sebagai berikut.

$$
\begin{aligned}
& 5=\text { Sangat tinggi } \\
& 4=\text { Tinggi } \\
& 3=\text { Cukup } \\
& 2=\text { Rendah } \\
& 1=\text { Sangat rendah }
\end{aligned}
$$

Perhitungan persepsi dilakukan dengan cara menghitung rata-rata dan menyusun kriteria penilaian dalam skala likert. Penyusunan kriteria ini berdasarkan kurva normal. Cara menyusun kriteria penilaian dalam skala likert dengan melihat kurva normal standar luasnya 6SD. Oleh karena itu bila memodifikasi model skala likert menjadi 4 kriteria maka luasan masing-masing kategri adalah 1,2 SDi (6/5 SDi). Sehingga kriterianya dapat dirumuskan sebagai berikut: 
Tabel 4. Rumusan Kriteria

\begin{tabular}{clc}
\hline No & \multicolumn{1}{c}{ Rentang Skor } & Kriteria \\
\hline 1. & $\begin{array}{l}\text { Mi+1,8 SDi } \leq \bar{X} \leq \mathrm{Mi} \\
+3,0 \mathrm{Sdi}\end{array}$ & Sangat Baik \\
2. & $\begin{array}{l}\text { Mi }+0,6 \mathrm{SDi} \leq \bar{X}<\mathrm{Mi} \\
+1,8 \mathrm{Sdi}\end{array}$ & Baik \\
3. & $\begin{array}{l}\text { Mi-0,6 SDi } \leq \bar{X}<\mathrm{Mi} \\
+0,6 \mathrm{Sdi}\end{array}$ & Cukup Baik \\
4. & $\begin{array}{l}\text { Mi }-1,8 \mathrm{SDi} \leq \bar{X}<\mathrm{Mi} \\
\text { 5. }\end{array}$ & Cukup \\
& Mi $-3 \mathrm{Sdi}$ & Kurang \\
& 1,8 Sdi & \\
\hline
\end{tabular}

Keterangan:

$\mathrm{Xi}=\frac{1}{2}($ skor tertinggi + skor terendah $)$

$\mathrm{SDi}=$ standar deviasi ideal $=\frac{1}{6}($ skor tetinggi skor terendah)

Tabel diatas diturunkan dari kurva normal terhadap skala likert

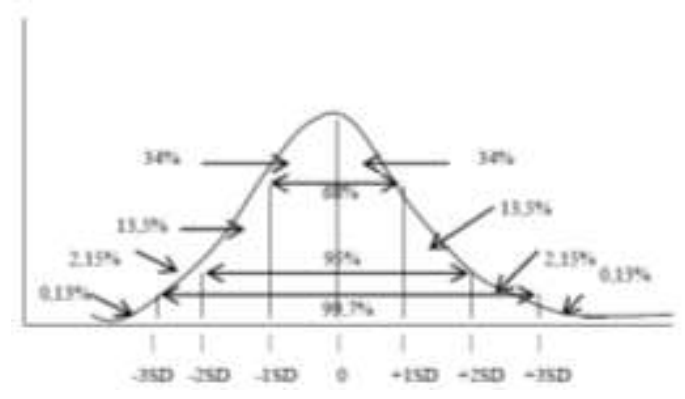

Gambar 2. Kurva Normal

(Sumber:Juknis Penilaian Afektif, 2010)

\section{Hasil Penelitian dan Pembahasan}

Modul cetak yang telah dikembangkan selanjutnya divalidasi. Validasi dilakukan untuk mendapat persetujuan dari para validator yang telah ditentukan. Untuk mendapat persetujuan ini, modul cetak akan mendapat penilaian dan saran perbaikan. Setelah mendapatkan penilaian dan saran dari para validator, maka langkah selanjutnya adalah melakukan revisi atau perbaikan terhadap modul cetak. Pada penelitian ini dilakukan validasi materi dan media oleh dua validator.

Proses validasi materi dilakukan sebanyak dua tahap dan validasi media dilakukan sebanyak dua tahap. Dari proses validasi materi dan media, para validator telah menyatakan bahwa modul cetak yang dikembangkan layak untuk diuji cobakan. Selanjutnya dilakukan uji coba kepada 30 mahasiswa Pendidikan Fisika Angkatan 2016 Universitas Jambi untuk melihat kelayakan modul cetak. Uji coba dilakukan dengan menyebarkan angket tertutup kepada mahasiswa dan menampilkan modul cetak. Dari uji coba yang telah dilakukan diperoleh data persepsi mahasiswa mengenai modul cetak yang dikembangkan. Hasil analisis persepsi mahasiswa pada aspek desain modul cetak yaitu memperoleh skor 85 (Sangat baik), aspek materi pembelajaran yaitu 85,07 (Sangat baik), aspek keterbacaan modul persepsi mahasiswa yaitu 85,22 (sangat baik), aspek visualisasi modul persepsi mahasiswa yaitu 84,11 (sangat baik). Dari keempat aspek tersebut diperoleh persentase rata-rata persepsi mahasiswa sebesar 84,73. Hasil ini menunjukkan bahwa modul cetak yang dikembangkan mendapatkan apresiasi positif dari mahasiswa.

\section{Simpulan dan Saran}

\section{Simpulan}

Simpulan dapat bersifat generalisasi temuan sesuai permasalah Simpulan

Modul cetak fisika pada materi fluida ini telah melalui proses validasi, baik validasi ahli materi maupun ahli validasi media. Proses validasi ini berlangsung dengan beberapa kali validasi disertai dengan adanya revisi untuk memperbaiki modul sesuai dengan penilaian dan saran yang diperoleh dari validator. Validasi materi berlangsung sebanyak dua kali yang dilakukan untuk memperoleh kelayakan modul dari aspek materi. Dari validasi ini, diperoleh hasil bahwa menurut pendapat para ahli, modul berbasis inkuiri yang telah dibuat dinyatakan layak diproduksi. Ini sesuai dengan kesimpulan hasil validasi dari dua validator yang telah mevalidasi modul tersebut

Setelah modul cetak dikatakan layak untuk diuji coba oleh tim ahli baik ahli materi maupun ahli media, maka langkah selanjutnya adalah analisis data persepsi mahasiswa terhadap modul elektronik. Hasil analisis persepsi mahasiswa pada aspek desain modul cetak yaitu memperoleh skor 85 (Sangat baik), aspek materi pembelajaran yaitu 85,07 (Sangat baik), aspek keterbacaan modul persepsi 
mahasiswa yaitu 85,22 (sangat baik), aspek visualisasi modul persepsi mahasiswa yaitu 84,11 (sangat baik). Dari keempat aspek tersebut diperoleh persentase rata-rata persepsi mahasiswa sebesar 84,73. Berdasarkan hasil yang diperoleh dalam penelitian dapat disimpulkan bahwa pengembangan modul cetak fisika pada materi fluida ini termasuk kategori baik dan layak digunakan mahasiswa sebagai bahan ajar mandiri.

Saran

Peneliti menyarankan kepada peneliti selanjutnya agar menambah contoh soal pada modul cetak agar dapat meningkatkan kemampuan kognitifnya dalam memahami konsep materi yang dipelajari dan menambah konsep-konsep pada modul. Peneliti juga menyarankan untuk dapat menguji pengaruh penggunaan modul cetak fisika pada materi fluida ini terhadap hasil belajar mahasiswa.an penelitian, dapat pula berupa rekomendatif untuk langkah selanjutnya.

\section{Daftar Pustaka}

Arikunto, Suharsimi. (2013). Dasar-Dasar Evaluasi Pendidikan Edisi 2. Jakarta: Bumi Aksara.

Daryanto. (2013). Menyusun Modul (Bahan Ajar untuk Persiapan Guru dalam Mengajar). Yogyakarta: Gava Media. referensi/acuan di dalam Daftar Pustaka, diberikan berikut.

Direktorat Pembinaan SMA. (2010). Juknis Penyusunan Perangkat Penilaian Afektif Di SMA.

https://www.academia.edu

/6530493/30.JJuknis_Penilaian_Afektif _ ISI-Revisi_0104. Diakses pada 20 Mei 2017

Sugiyono, (2013). Metode Penelitian Pendidikan: Pendekatan Kuantitatif, Kualitatif, dan R\&D. Bandung: Alfabeta.

Trianto. (2017). Model Pengembangan Terpadu (Konsep, Strategi, dan Implementasinya dalam KTSP). Jakarta: Bumi Aksara.

Widoyoko, Eko Putro. (2015). Teknik Penyusunan Instrumen Penelitian. Yogyakarta: Pustaka Pelajar. 